\title{
Cephalic phase of pancreatic secretion in man
}

\author{
H. SARLES, R. DANI, G. PREZELIN, C. SOU VILLE, \\ AND C. FIGARELLA \\ From Unite de Recherches de Pathologie Digestive de L'Institut National de la \\ Santé et de la Recherche Médicale, Hôpital Ste Marguerite, Marseille
}

The pancreatic secretory response to sham feeding was shown by Pavlov (1902). According to Gregory (1962), in the conscious dog 'sham feeding causes only a scanty flow of (pancreatic) juice rich in enzymes, provided that the gastric juice secreted at the same time is prevented from entering the duodenum and so liberating secretin (Walther, 1897; Krewer, 1899; Tonkich, 1924; Ivy and Crittenden, 1937). Secretion begins a minute or two after the start of feeding and lasts in all about 30 minutes; the volume is small (less than $10 \mathrm{ml}$ ) and there is thus no indication that such vagal excitation causes any release of secretin'. For Ivy (1926), 'the cephalic phase [of pancreatic secretion] is so small that it is not important.'

More recently Preshaw, Cooke, and Grossman (1966) have shown that sham feeding causes a marked increase in pancreatic secretion in dogs with permanent pancreatic fistulas. This pancreatic response is inhibited by acidification of an innervated pouch of the pyloric gland area and the authors suggest that it is mediated by the vagal release of secretin. In the rat, sham feeding seems not to have any effect on pancreatic secretion if the animals are provided with a gastric fistula or vagotomized (Alphin and Lin, 1959).

Little is known about the cephalic phase of pancreatic secretion in man. The observations of Kogen (1931) on 17 patients are open to criticism because gastric juice was not prevented from entering the duodenum: the increased pancreatic response after sham feeding may not be a true cephalic phase but secondary to the $\mathrm{HCl}$ produced during the cephalic phase of gastric secretion (Alphin and Lin, 1959). In a man with a pancreatic fistula neither Villaret and Justin-Besancon (1936) nor Sinclair (1956) were able to stimulate pancreatic secretion when appetizing food was shown to the patient.

The purpose of our experiments was to investigate whether cephalic stimulation influences pancreatic function in man.

\section{METHODS}

In most of the observations the subjects were volunteers or convalescent patients without gastrointestinal disease and in a normal nutritional condition. In some experiments we also studied cholecystectomized patients with apparently normal pancreas and patients with chronic calcifying pancreatitis.

Gastric juice was prevented from entering the duodenum by using a modified double-lumen tube. The duodenal portion of the tube measured $25 \mathrm{~cm}$, and had six holes. It contained a metallic chuck, which facilitates passage into the pylorus. The gastric portion of the tube also had six holes. Between the gastric and the duodenal portions the tube was surrounded by a small rubber balloon $(9 \times 3 \mathrm{~cm})$, which could be inflated by a third tube $2 \mathrm{~mm}$ in diameter.

After an overnight fast, an injection of $0.2 \mathrm{~g}$ phenobarbital was given and 15 minutes later the tube was inserted as far as the pylorus with the metallic chuck in place. The chuck was then pulled back a distance of $20 \mathrm{~cm}$ and the end of the tube pushed inside the duodenum, under fluoroscopic control. The balloon was inflated with $30 \mathrm{ml}$ air. The insertion of the tube usually required about 15 minutes. The patient was then laid down on his left side: this position is essential to ensure occlusion of the pylorus. The efficacy of the balloon in preventing leakage of gastric juice into the duodenum was checked by injecting bromsulphalein (B.S.P.) into the stomach at the beginning of the experiment. When B.S.P. was found in the duodenum the experiment was discarded. About 30 minutes after the phenobarbital injection, suction of gastric and duodenal juice was started, under a steady negative pressure of $20 \mathrm{~cm}$ water.

Three types of cephalic stimulation were used. In A a beefsteak was grilled in the same room and in $A^{1}$ the more usual French breakfast of rolls and coffee was substituted. In these two types of experiments the patient was allowed to see and smell the food for five minutes, after which it was removed. In B the patient was given a quantity of beefsteak previously grilled in another room and instructed to chew this quickly, then remove it from his mouth, which he rinsed with water. In every case, the patients knew they would have a well prepared meal after the experiment but they were unaware of the purpose or sequence of the experiments. The first stimulus was applied after control collections of gastric and duodenal juice for 60 minutes. Pancreatic and gastric juices were collected in bottles immersed in crushed ice and changed every $15 \mathrm{~min}$ except for the $20 \mathrm{~min}$ following each stimulation, during which successive two minute fractions were collected.

Bicarbonate was estimated by the Van Slyke method, 
amylase by the Lagerlöf method (1942), and lipase estimated as described previously by Sarles, Taulier, and Figarella (1963). Lipase was chosen because its secretion has been shown to be more regular (Sarles, Bauer, and Prezelin, 1965), but in nine patients amylase, chymotrypsin, and trypsin were also measured with specific substrates (Figarella, Taulier, and Sarles, 1965).

To achieve success in this experimental procedure every effort must be made to have the full confidence of the subject under test. Unless the patient is completely relaxed and tranquil the cephalic response may be lost.

\section{RESULTS}

EFFECT ON THE PANCREATIC RESPONSE OF THE NATURE AND TIMING OF STIMULI In these experiments the basal secretion before the first stimulation is expressed as the mean output in 30 minutes of water (ml), bicarbonate (m-equiv/l), lipase, trypsin, chymotrypsin (international units $=$ m-equiv of substrate hydrolysed in one minute) and amylase (LagerlöfNörby units). The effect of stimulation is measured by the difference between the 30 minutes' secretion after stimulation and the $\mathbf{3 0}$ minutes' basal secretion.

In five patients type $\mathrm{A}$ (visual and olfactory stimulation was applied 60 minutes after intubation at approximately 10.30 a.m.) followed by type B (sham feeding) after a further 60 minutes. Both types of stimulation were followed by an increase in the volume and the bicarbonate and lipase contents of duodenal juice (Table I). In three patients, this increase started after two minutes, and in two patients after four minutes. All patients showed a maximum response after 10 minutes with a decline thereafter, leading to a plateau response which persisted into the subsequent period of sham feeding. The second (type B) stimulus provoked a similar but even greater response than the first. Gastric secretion occurred later than duodenal flow, the delay varying from four to 18 minutes, and in three patients gastric secretion was inhibited for 12 to 15 minutes before the response to the sham feeding began.

To determine whether the time at which sham feeding occurred was important, four patients were given type $A$ at 8.30 a.m., type $A$ again at 10.30 a.m., and then type B at 11.30 a.m. (Table II and Fig. 1). In these experiments the first stimulus caused inhibition of duodenal flow followed by a weak excitation, but the second and third were always followed by a great increase in duodenal juice, after the usual delay of two to four minutes. Gastric flow

TABLE I

RESULTS OF TYPES A AND B SHAM FEEDING

\begin{tabular}{|c|c|c|c|c|c|c|c|c|c|c|}
\hline \multirow[b]{2}{*}{$\begin{array}{l}\text { Case } \\
\text { No. }\end{array}$} & \multirow[b]{2}{*}{$\begin{array}{l}\text { Age } \\
(y r)\end{array}$} & \multicolumn{3}{|c|}{ Basal Secretion } & \multicolumn{3}{|c|}{$\begin{array}{l}\text { Type of Sham Feeding } \\
A\end{array}$} & \multicolumn{3}{|l|}{$\boldsymbol{B}$} \\
\hline & & $\begin{array}{l}\text { Lipase } \\
\text { (units) }\end{array}$ & $\begin{array}{l}\text { Volume } \\
(\mathrm{ml})\end{array}$ & $\begin{array}{l}\mathrm{CO}_{3} \\
\text { (m-equiv) }\end{array}$ & $\begin{array}{l}\text { Lipase } \\
\text { (units) }\end{array}$ & $\begin{array}{l}\text { Volume } \\
(\mathrm{ml})\end{array}$ & $\begin{array}{l}\mathrm{CO}_{8} \\
\text { (m-equiv) }\end{array}$ & $\begin{array}{l}\text { Lipase } \\
\text { (units) }\end{array}$ & $\begin{array}{l}\text { Volume } \\
(\mathrm{ml})\end{array}$ & $\begin{array}{l}\mathrm{CO}_{\mathrm{s}} \\
\text { (m-equiv) }\end{array}$ \\
\hline $\begin{array}{l}144 \\
145 \\
143 \\
147 \\
146\end{array}$ & $\begin{array}{l}24 \\
69 \\
25 \\
26 \\
36\end{array}$ & $\begin{array}{l}20,917 \\
40,250 \\
19,340 \\
37,940 \\
22,800\end{array}$ & $\begin{array}{l}15 \\
28 \\
30 \cdot 6 \\
31 \cdot 5 \\
16\end{array}$ & $\begin{array}{l}0.50 \\
0.65 \\
0.86 \\
0.88 \\
0.55\end{array}$ & $\begin{array}{r}+83,167 \\
+52,214 \\
+87,500 \\
+66,566 \\
+40,819\end{array}$ & $\begin{array}{l}+47 \\
+30 \\
+35 \\
+32 \\
+25\end{array}$ & $\begin{array}{l}+1.90 \\
+1.05 \\
+1.56 \\
+1.35 \\
+1.60\end{array}$ & $\begin{array}{rr}+ & 114,971 \\
+\quad 85,154 \\
+\quad 170,605 \\
+\quad 209,326 \\
+\quad 76,443\end{array}$ & $\begin{array}{l}+58 \\
+43 \\
+62 \\
+86 \\
+33\end{array}$ & $\begin{array}{l}+3.55 \\
+1.86 \\
+3.52 \\
+4.97 \\
+2.54\end{array}$ \\
\hline
\end{tabular}

${ }^{1}$ In all the tables a plus sign indicates an increase over basal values and minus sign a decrease.

If stimulation produced inhibition followed by an increased response, two values are given.

TABLE II

RESULTS OF SHAM FEEDING TYPE A TWICE AND TYPE B ONCE

\begin{tabular}{|c|c|c|c|c|c|c|c|c|c|c|c|c|c|}
\hline \multirow[b]{3}{*}{$\begin{array}{l}\text { Case } \\
\text { No. Sex }\end{array}$} & \multirow[b]{3}{*}{$\begin{array}{c}\text { Age } \\
(y r)\end{array}$} & \multicolumn{3}{|c|}{ Basal Secretion } & \multicolumn{9}{|c|}{ Type of Sham Feeding } \\
\hline & & \multirow[b]{2}{*}{$\begin{array}{l}\text { Lipase } \\
\text { (units) }\end{array}$} & \multirow[b]{2}{*}{$\begin{array}{l}\text { Volume } \\
(\mathrm{ml})\end{array}$} & \multirow[b]{2}{*}{$\begin{array}{l}\mathrm{CO}_{3} \\
\text { (m-equiv) }\end{array}$} & \multicolumn{3}{|c|}{ A at 8.30 a.m. } & \multicolumn{3}{|c|}{ A at 10.30 a.m. } & \multicolumn{3}{|l|}{$\boldsymbol{B}$} \\
\hline & & & & & $\begin{array}{l}\text { Lipase } \\
\text { (units) }\end{array}$ & $\begin{array}{l}\text { Volume } \\
(\mathrm{ml})\end{array}$ & $\begin{array}{l}\mathrm{CO}_{3} \\
\text { (m-equiv) }\end{array}$ & $\begin{array}{c}\text { Lipase } \\
\text { (units) }\end{array}$ & $\begin{array}{l}\text { Volume } \\
(\mathrm{ml})\end{array}$ & $\begin{array}{l}\mathrm{CO}_{3} \\
\text { (m-equiv) }\end{array}$ & $\begin{array}{l}\text { Lipase } \\
\text { (units) }\end{array}$ & $\begin{array}{l}\text { Volume } \\
(\mathrm{ml})\end{array}$ & $\begin{array}{l}\mathrm{CO} \\
\text { (m-equiv) }\end{array}$ \\
\hline 192 ๆ & 43 & 20,470 & $21 \cdot 7$ & 0.05 & $\begin{array}{r}9,520 \\
+\quad 6,270\end{array}$ & $\begin{array}{l}-5 \cdot 2 \\
+\quad 3.2\end{array}$ & $+0 \cdot 125$ & $+70,400$ & +41 & +2.03 & $+108,700$ & +55 & +3.46 \\
\hline 193 ㅇ & 65 & 20,590 & $19 \cdot 5$ & 0.38 & $\begin{array}{r}-5,800 \\
+\quad 2,075\end{array}$ & $\begin{array}{l}-3.6 \\
+\quad 1.4\end{array}$ & +0.09 & $+64,450$ & +49 & +2.62 & $+90,762$ & +63 & $+4 \cdot 39$ \\
\hline 207 ? & 38 & 22,085 & $23 \cdot 7$ & 0.54 & $\begin{array}{r}-5,350 \\
+\quad 4,790\end{array}$ & $\begin{array}{r}-4.8 \\
+3.5\end{array}$ & +0.05 & $+38,040$ & +24 & +1.45 & 77,000 & +45 & $+4 \cdot 70$ \\
\hline $208 \sigma$ & 30 & 29,800 & $30 \cdot 25$ & $1 \cdot 24$ & $\begin{array}{l}-3,200 \\
+\quad 2,900\end{array}$ & $\begin{array}{l}-5.5 \\
+0.5\end{array}$ & $\begin{array}{l}-0.16 \\
+0.07\end{array}$ & $+49,750$ & +23 & +1.53 & $+82,560$ & +41 & $+3 \cdot 23$ \\
\hline
\end{tabular}




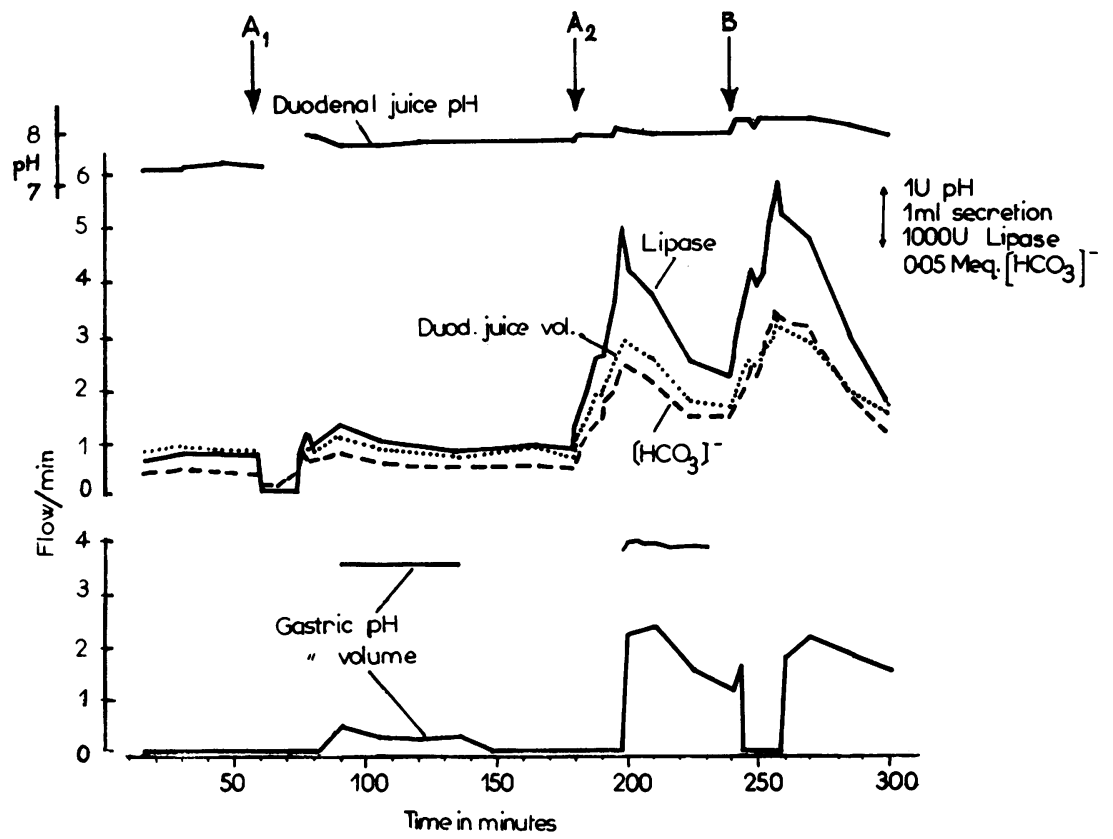

FIG. 1. Response to early and late type A psychic stimulation and of type $B$ sham feeding.

increased 12-15 minutes after the first stimulation whereas pancreatic secretion remained inhibited or weak.

The effect of palatability on psychic stimulation was investigated by substituting type $\mathbf{A}^{1}$ stimulation for type $A$ at 8.30 a.m., meat being an unusual item for breakfast in France. In five patients, $A^{1}$ sham feeding was never followed by an inhibition, but by a small augmentation (Table III and Fig. 2). In one anorectic patient in whom this experiment was performed the repeated stimuli had diminishing effects and produced growing inhibition (case 206, Table III).

EFFECT OF ANTICHOLINERGIC DRUGS ON THE CEPHALIC RESPONSE In these experiments type A was followed by type B stimulation, as in the first series, but an anticholinergic drug was administered 15 minutes before the second stimulus. We measured (a) the duration of the inhibition from the beginning of the decrease of flow to the return to basal secretion, and (b) the duration of the secretory wave following the second stimulus after injection of the drug. For lipase, bicarbonate, and volume we calculated the ratio of the response to the type $B$ stimulation (after the anticholinergic drug) to that following the first type A stimulation (before the anticholinergic drug).

In three patients $1 \mathrm{mg}$ atropine was given intravenously 15 minutes before the type B sham feeding. The results did not differ markedly from those of Table I and atropine was abandoned for a more powerful anticholinergic, because its side effects did not permit the use of such high doses as in

TABLE III

RESULTS OF SHAM FEEDING TYPES A $^{\mathbf{1}}$, A, AND B

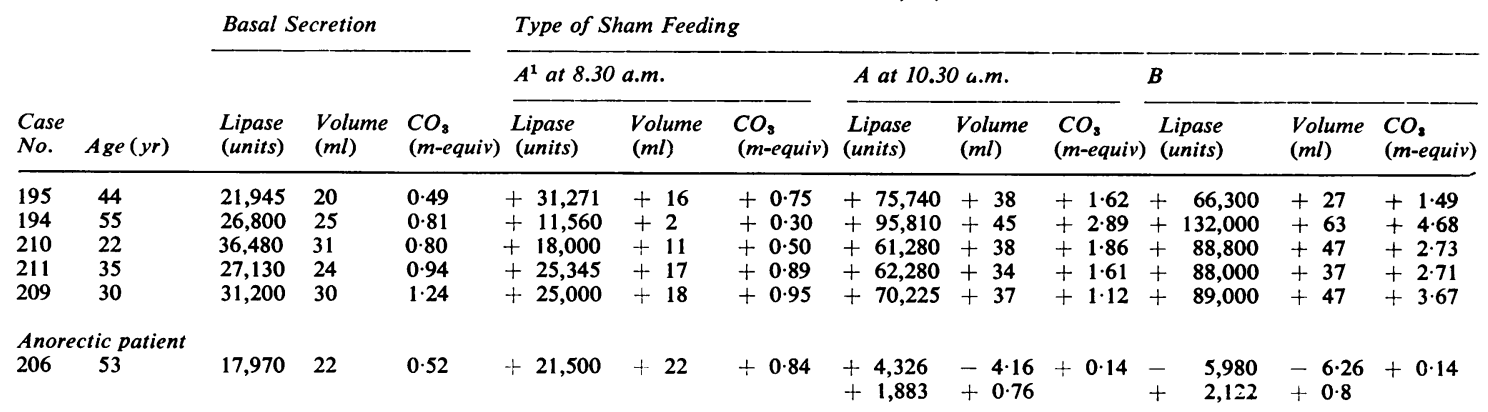




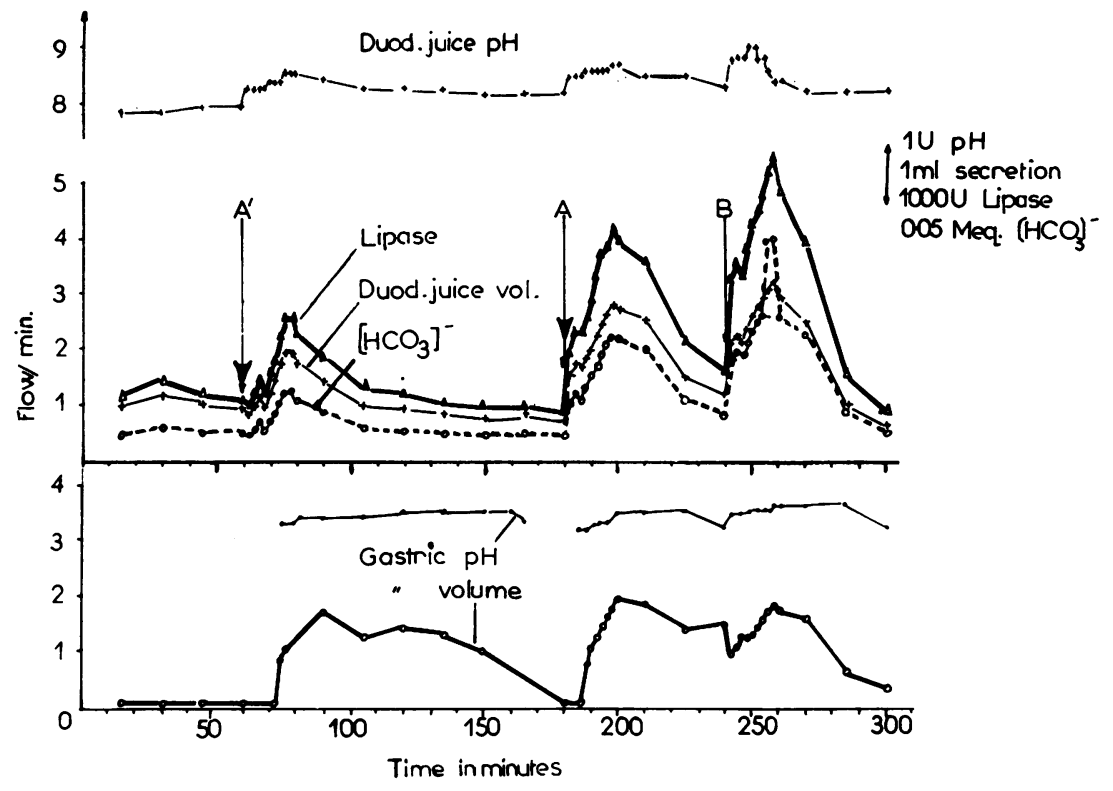

FIG. 2. An experiment similar to that in Figure 1 , except that type $A^{1}$ replaces type $A$ stimulation at 8.30 a.m.

animals. In four patients, in whom $3 \mathrm{mg}$ Priamide (2-2 diphenyl, 4 diisopropylaminobutyramide methyl iodide) was substituted for atropine, pancreatic and gastric secretion was markedly inhibited and lasted up to 100 minutes. Nevertheless the second stimulus was still able to produce a slight response, lasting 14-21 minutes instead of the usual minimum of one hour (Table IV).

\section{TABLE IV}

ACTION OF ANTICHOLINERGIC DRUG PRIAMIDE

\begin{tabular}{|c|c|c|c|c|c|c|}
\hline \multirow{2}{*}{\multicolumn{2}{|c|}{$\begin{array}{l}\text { Case } \\
\text { No.Sex Age (yr) }\end{array}$}} & \multirow{2}{*}{$\begin{array}{l}\text { Duration } \\
\text { of } \\
\text { Inhibition } \\
\text { (min) }\end{array}$} & \multirow{2}{*}{$\begin{array}{l}\text { Duration } \\
\text { of } \\
\text { Response } \\
\text { to } B \text { (min }\end{array}$} & \multicolumn{3}{|c|}{ Maximum Activity } \\
\hline & & & & Lipase & $\mathrm{CO}_{3} \mathrm{NaH}$ & Volume \\
\hline 156 우 & 36 & 105 & 20 & 0.61 & 0.32 & 0.57 \\
\hline 157 우 & 25 & 115 & 14 & 0.60 & 0.39 & 0.59 \\
\hline 166 우 & 56 & 105 & 21 & 0.57 & 0.43 & 0.64 \\
\hline 167 ㅇ & 36 & 115 & 20 & 0.68 & 0.59 & 0.70 \\
\hline
\end{tabular}

A COMPARISON OF THE RESPONSE TO PSYCHIC STIMULATION AND TO SECRETIN + PANCREOZYMIN In 32 subjects (16 normal controls, 13 cases of chronic calcifying pancreatitis, and three cholecystectomized patients with apparently normal pancreas) a type A stimulus was given at 10.30 a.m. and an intravenous injection of $1 \mathrm{u} / \mathrm{kg}$ of secretin (Boots) $+3 \mathrm{u} / \mathrm{kg}$ of pancreozymin (Boots) at 11.30 , except that in four patients the order of excitation was inverted without any noticeable change in the secretory responses. The duodenal juice was collected in successive 10-minute samples. In assessing the responses we compared the bicarbonate concentration (m-equiv/1) and output of enzymes (u/min) in the most active sample after each stimulation.

In all three groups of patients the secretion of lipase was higher after psychic stimulation than after pancreozymin + secretin (probability calcu-

TABLE V

SECRETION OF LIPASE

\begin{tabular}{|c|c|c|c|c|c|c|}
\hline & $\begin{array}{l}\text { Lipase } \\
\text { (units/minute) } \\
\text { Basal } \\
\text { Secretion }\end{array}$ & $\begin{array}{l}\text { After } \\
\text { Sham Feeding }\end{array}$ & $\begin{array}{l}\text { Secretin and } \\
\text { Pancreozymin }\end{array}$ & $\begin{array}{l}\mathrm{CO}_{3} \\
\text { (m-equiv/l) } \\
\text { Basal } \\
\text { Secretion }\end{array}$ & $\begin{array}{l}\text { After } \\
\text { Sham Feeding }\end{array}$ & $\begin{array}{l}\text { Secretin and } \\
\text { Pancreozymin }\end{array}$ \\
\hline $\begin{array}{l}16 \\
\text { Controls } \\
13 \text { cases of } \\
\text { Pancreatitis } \\
13 \\
\text { cholecystectomized } \\
\text { patients } \\
{ }^{1} \text { Mean } \\
{ }^{2} \text { Range }\end{array}$ & $\begin{array}{l}1,200 \\
(900-1500) \\
1,200 \\
(50-600) \\
600 \\
(500-700)\end{array}$ & $\begin{array}{l}8,500 \\
(4,600-13,800) \\
1,400 \\
(100-2,900) \\
6,700 \\
(6,300-7,200)\end{array}$ & $\begin{array}{l}4,800 \\
(3,100-6,900) \\
800 \\
(50-1,900) \\
5,000 \\
(2,600-8,800)\end{array}$ & $\begin{array}{l}22 \\
(13-28) \\
14 \\
(16-25) \\
15 \\
(13-17)\end{array}$ & $\begin{array}{l}43 \\
(22-99) \\
19 \\
(7-34) \\
42 \\
(19-88)\end{array}$ & $\begin{array}{l}84 \\
(58-123) \\
36 \\
(12-73) \\
88 \\
(79-93)\end{array}$ \\
\hline
\end{tabular}




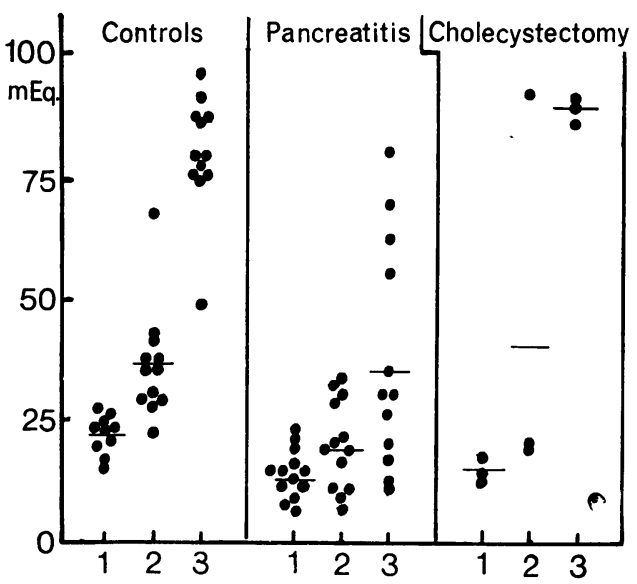

FIG. 3. Maximum concentration of bicarbonate in 15 minutes samples: (1) in basal secretion; (2) after type $A$ sham feeding; (3) after intravenous injection of $1 \mathrm{u} / \mathrm{kg}$ of secretin and $1 \mathrm{u} / \mathrm{kg}$ of pancreozymin.

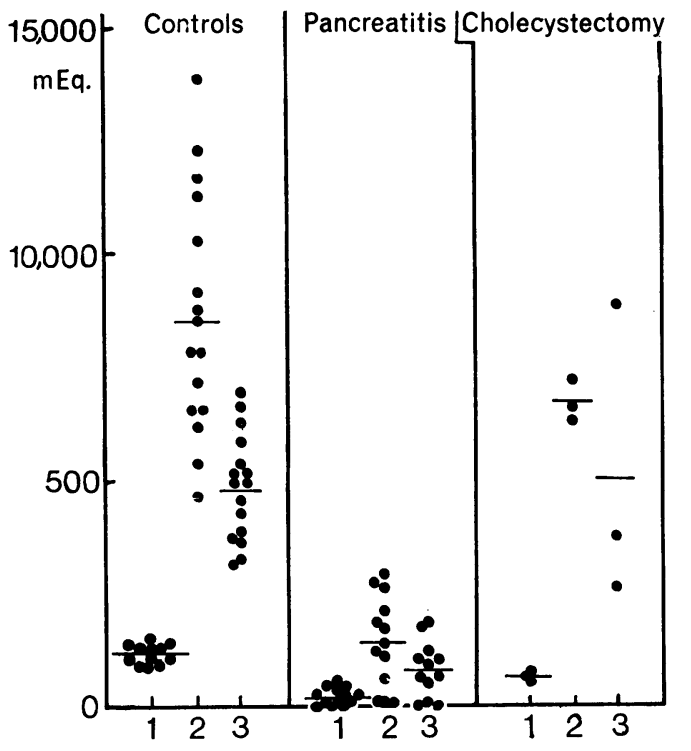

FIG. 4. Maximum output of lipase in one minute in the most active 15-minute sample as in Figure 3.

lated by the Sign test (Siegel, 1956) $(\mathrm{p}<0.00003)$. The reverse was the case for the secretion of water and bicarbonate $(p<0.00003)$ (Table IV and Figs. 3 and 4). In seven people (three cholecystectomized patients with normal pancreas and four patients with pancreatic insufficiency), the output of amylase, trypsin, and chymotrypsin was estimated in addition to lipase and bicarbonate (Table VI and Fig. 5). The probabilities for psychic stimulation leading to a greater output of enzymes than secretin + pancreozymin are 0.016 for amylase, 0.109 for trypsin and chymotrypsin (Sign test). The parallel of the secretion of the four enzymes was almost perfect in the three cholecystectomized patients, and indisputable but imperfect in the others, both after psychic stimulation and after secretin + pancreozymin.

\section{TABLE VI}

OUTPUT OF AMYLASE, TRYPSIN, AND CHYMOTRYPSIN

\begin{tabular}{llcl}
\multicolumn{5}{c}{ Amylase (units/minute) } \\
\cline { 2 - 4 } & $\begin{array}{lll}\text { Basal } \\
\text { Secretion }\end{array}$ & $\begin{array}{l}\text { After Sham } \\
\text { Feeding }\end{array}$ & $\begin{array}{l}\text { After Secretin } \\
\text { and } \\
\text { Pancreozymin }\end{array}$ \\
\hline Pancreatitis & 1.4 & 2.9 & 1.7 \\
& 0.6 & 0.8 & 0 \\
Cholecystectomized & 0.7 & 2.3 & 0.5 \\
& 1.3 & 2.8 & 2.5 \\
& 0.9 & 34 & 2 \\
& 0.9 & 1.3 & 11
\end{tabular}

Pancreatitis

Trypsin (units/minute)

$\begin{array}{cc}\text { Trypsin (units/minute) } \\ 1 & 5 \\ 1 & 2 \\ 0 & 3 \\ 12 & 98\end{array}$

$$
2
$$

\section{2}

12

Cholecystectomized 31

$31 \quad 121$

$\begin{array}{rr}21 & 126 \\ 100 & 85\end{array}$

Pancreatitis

Chymotrypsin (units/minute)

$\begin{array}{ccr}\text { Chymotrypsin (units/minute) } & \\ 0 & 2 & 2 \\ 1 & 4 & 0 \\ 0 & 0 & 2 \\ 18 & 70 & 43 \\ & & \\ 98 & 360 & 150 \\ 32 & 180 & 160\end{array}$

$\begin{array}{rr}\text { Cholecystectomized } & 98 \\ 32\end{array}$

\section{DISCUSSION}

Our observations support the existence of a cephalic phase of pancreatic secretion in man. Before reaching a definite conclusion certain points require discussion.

The presence of a tube in the duodenum and the stomach may modify the pancreatic secretion, and it has been shown that the collection of juice, without subsequent return to the duodenum, augments the pancreatic secretion of water, bicarbonate, and, to a smaller extent, protein (Annis and Hallenbeck, 1951). Furthermore the distension of the pyloric area by the balloon may cause a gastro-pancreatic reflex (White, Lundh, and Magee, 1960; White, Alexander, and Magee, 1963). However, the balloon used by White $e t$ al. in man was inflated with 200 to $400 \mathrm{ml}$ of air, compared with the $30 \mathrm{ml}$ used in our experiments.

It is also possible that the tube and the balloon may stimulate a harmonal gastro-pancreatic mechanism (Blair, Clark, Harper, Lake, and Scratcherd, 1961; Preshaw et al., 1966). As the balloon was 


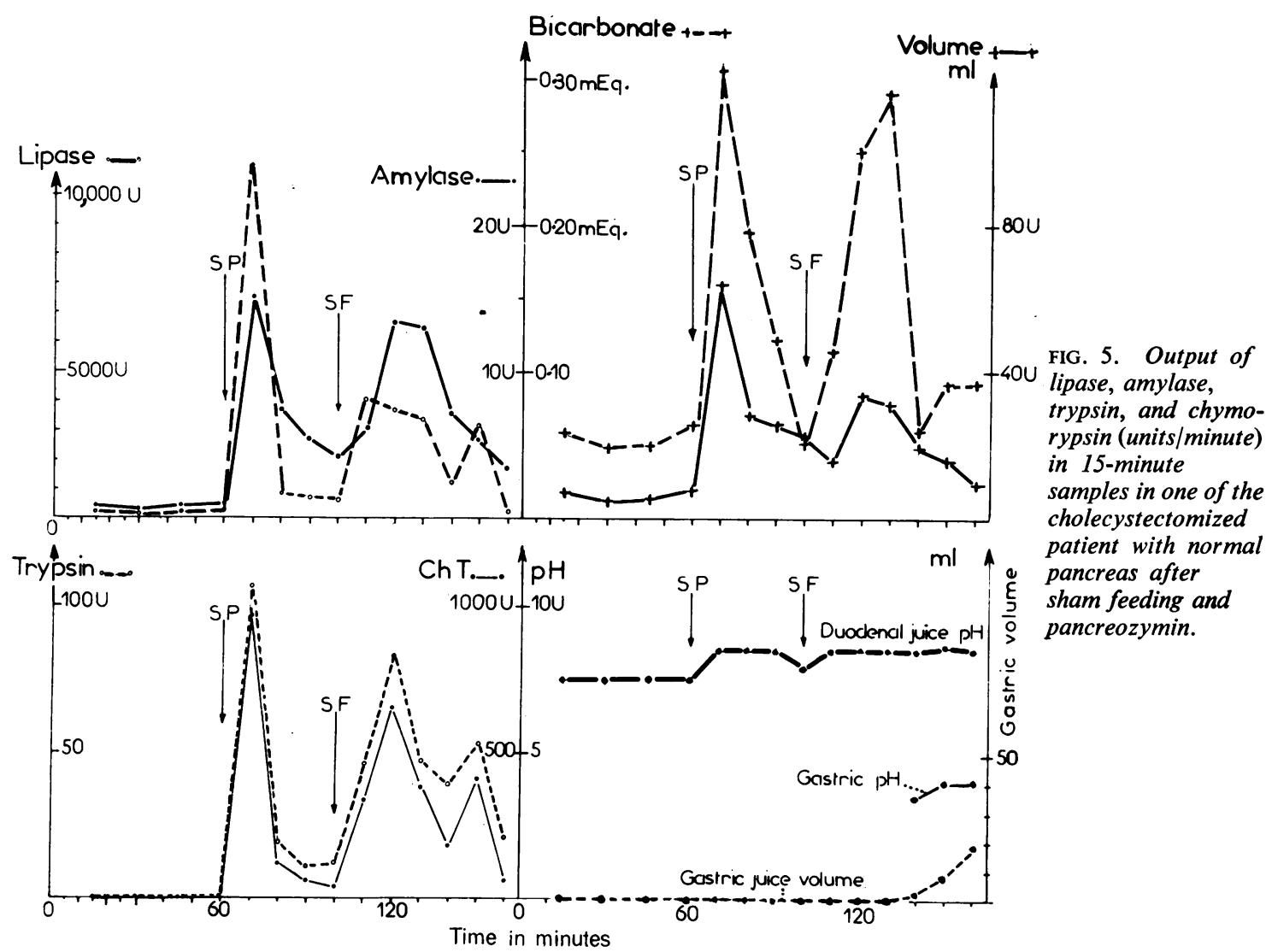

distended throughout our experiments, this could not explain the results, although it might, by providing a subthreshold background stimulus, have made the pancreas more sensitive to psychic stimulation.

The action of phenobarbital has been described in a previous paper (Sarles et al., 1965). It does not modify significantly the action of cephalic stimulation. In any case, the interval between the phenobarbital injection and the first stimulation was the same in each experiment, except in those in which secretin was infused continuously.

The secretion of pancreatic juice starts within two to four minutes of stimulation. That this secretion is not provoked by gastric juice in the duodenum is shown by (a) the absence of B.S.P from the duodenal aspirate; (b) the absence of any evidence that gastric and pancreatic responses have a parallel course; and (c) the fact that gastric secretion almost always began later than pancreatic flow. This last point was noted by Pavlov (1902, p. 124) in dogs and regarded by him as a very strong argument in favour of the view that the pancreatic response was a true nervous reflex and not secondary to the passage of gastric acid from the stomach to the intestine: ' . . . But there was another way by which the matter might be decided, viz., the determination of the latent period of sham feeding for the pancreas. The latent period of the gastric secretion in dogs has a sharply marked lower limit, and is never less than four and a half minutes. The pancreatic juice, on the contrary, begins to flow two to three minutes after the application of the exciting agency, for example, an acid. In the experiment of teasing the animal by offering it food, the pancreatic flow also generally begins after two to three minutes. This appears to me to point to a direct psychic influence through the secretory nerves of the pancreas, such as has long been established for the secretory mechanism of the stomach ...'

Forell and Strahlheber (1966) consider that in man lipase and trypsin secretions are dependent on the amount of bile present in the duodenum. Kuroyanagi, Chiles, and Necheles (1962) also found that the administration of sodium dehydrocholate to the dog considerably enhanced pancreatic 
secretion induced by secretin. It was observed in our experiments that the highest pancreatic output of enzymes, water, and bicarbonate generally coincided with the greatest concentration of bile pigments (judged by the darkness of the duodenal juice). However, the presence of a normal response to psychic stimulation in cholecystectomized patients sufficiently proves that the excretion of gallbladder bile into the duodenum is not the cause of the pancreatic response.

The pancreatic response to psychic stimulation has been compared to the action of $1 \mathrm{u} / \mathrm{kg}$ of secretin (Boots) intravenously injected with $3 \mathrm{u} / \mathrm{kg}$ of pancreozymin (Boots). The ratio between the means of the output of lipase after psychic stimulation and after secretin + pancreozymin does not differ in controls (1.77) and in patients with pancreatic insufficiency $(1 \cdot 75)$, the enzymatic response being significantly higher after psychic stimulation. As the dose of $3 \mathrm{u} / \mathrm{kg}$ of pancreozymin is quite considerable this difference emphasizes the magnitude in man compared with the dog. The duration of the pancreatic secretion seems to be much longer in man (lasting at least one hour for a stimulus of five minutes) than in the dog. The cephalic phase of pancreatic secretion may therefore play in man a great and sustained part in the pancreatic enzyme response to food.

The action on water and bicarbonate secretion seems to be absent in the dog, and is disputable in man. The increase of water and bicarbonate output after cephalic stimulation could be explained by a secretion of bile which is fairly rich in bicarbonate. Hepatic bile in man contains 20-55 m-equiv/1 bicarbonate (Thureborn, 1962), the concentration of gallbladder bile being much lower (Diamond, 1965). In three controls and one cholecystectomized patient in our series the bicarbonate concentration after cephalic stimulation was higher than in a pure bile secretion (respectively 67, 67, 99, and 88 m-equiv/1). It should nevertheless be mentioned that in the cat secretin (Scratcherd, 1965) and in the dog gastrin (Zaterka and Grossman, 1966) increase the bicarbonate concentration of hepatic bile up to 60 to $70 \mathrm{~m}$-equiv/1. The parallel decrease in the responses to psychic stimulation and to secretin in the patients with chronic pancreatitis also favours the view that the bicarbonate secretion after psychic stimulation is at least in part of pancreatic origin. The secretion of water and bicarbonate, if in fact due to a direct action of cephalic stimulation on the pancreas, is nevertheless much less important than the secretion of enzymes, being lower than the secretion following $1 \mathrm{u} / \mathrm{kg}$ of secretin.

The mechanism of the cephalic phase of pancreatic secretion in the dog was attributed by Pavlov
(1902) to a direct vagal action and by Preshaw et al. (1966) in part to a secretion of gastrin by the antral area. The fact that the pancreatic and the gastric secretions do not have a parallel course does not favour the hypothesis that a prominent part is played by gastrin. The inhibitory effect of priamide, which has a strong anticholinergic action (Van Proosdij-Hartzema, Janssen, and De Jongh, 1955), suggests that in man as in animals the vagus plays an important part. The inefficacy of $1 \mathrm{mg}$ of intravenously injected atropine in decreasing the pancreatic secretion is probably due to the impossibility of using in man as high doses as in animals.

It is well known that appetite influences the response to cephalic stimuli, and this is supported by the poor results in one anorectic patient. One might extend this idea to explain the poor responses to psychic stimulation early in the day, when in fact basal secretion is depressed. Gastric secretion seems less dependent on the time of stimulation, and the early morning stimulus which inhibits pancreatic flow increased gastric secretion. The disparity between the effects of type $A$ and type $A^{1}$ stimuli in the early morning is probably related to the dietary habits of the patients studied and underlines the importance of being conditioned to foods. The outputs of amylase, lipase, trypsin, and chymotrypsin after cephalic stimuli follow a parallel course.

We thank Professor A. A. Harper of Newcastle, and Dr. H. Howat of Manchester who corrected the manuscript and made useful suggestions.

\section{REFERENCES}

Alphin, R. S., and Lin, T. M. (1959). Effect of feeding and sham feeding on pancreatic secretion of the rat. Amer. J. Physiol., 197, 260-262.

Annis, D., and Hallenbeck, G. A. (1951). Effect of excluding pancreatic juice from duodenum on secretory response of pancreas to a meal. Proc. Soc. exp. Biol. (N.Y.), 77, 383-385.

Blair, E. L., Brown, J. C., Harper, A. A., and Scratcherd, T. (1966). A gastric phase of pancreatic secretion. J. Physiol. (Lond.), 184, 812-824.

- Clark, D. G., Harper, A. A., Lake. H., and Scratcherd, T. (1961). A gastric phase of pancreatic secretion in cats. $J$. Physiol. (Lond.), 157, 17p.

Diamond, J. M. (1965). The concentrating activity of the gallbladder. In The Biliary System. A Symposium of the NATO Advanced Study Institute, edited by W. Taylor, pp. 495-514. Blackwell, Oxford.

Figarella, C., Taulier, J., and Sarles, H. (1965). Dosage de la chymo. trypsineet de la trysine dans le suc duodénal. Bull. Soc. Chim biol. (Paris), 47, 679-686.

Forell, M. M., and Strahlheber, H. (1966). Gallefluss und PankreasseKretion. Klin. Wschr., 44, 1184-1189.

Gregory, R. A. (1962). Secretory Mechanisms of the Gastro-Intestinal Tract, p. 145. Arnold, London.

lvy, A. C. (1926). Recent advances in the physiology of gastric and pancreatic secretion. North w. Med. (Seattle), 25, 589-592.

Kogen, B. E. (1931). Über den Einfluss des bedingten Nahrungsreizes auf die exkretorische Pankreasfunktion. Z. Klin. Med., 117, 203-209.

Kuroyanagi, Y., Chiles, T., and Necheles, H. (1962). Effect of bile salt on pancreatic secretion of the dog. Amer. J. Physiol., 203, 241-242. 
Lagerlöf, H. (1942). Pancreatic Function and Pancreatic Disease. MacMillan, New York. (Also Acta med. scand., suppl. 128).

Pavlov, I. P. (1902). The Work of the Digestive Glands. Translated by W. T. Thompson. Griffin, London.

Preshaw, R. M., Cooke, A. R., and Grossman, M. I. (1966). Sham feeding and pancreatic secretion in the dog. Gastroenteroiogy, 50, $171-178$.

Sarles, H., Bauer, J. B., and Prezelin, G. (1965). Etude des injections répétées et des perfusions de sécrétine chez I'homme. Arch. Mal. Appar. dig., 54, 177.

ment différent de la lipase, de l'amylase et des enzymes protéolytiques pancréatiques aprés différents modes d'excitation du pancréas humain. Bull. Soc. Chim. biol. (Paris), 48, 951-957.

_- Taulier, J., and Figarella, C. (1963). Dosage de la lipase dans le suc duodénal. Rev. franc Étud. clin. biol., 8, 706-707.

Scratcherd, T. (1965). Electrolyte composition and control of biliary secretion in the cat and rabbit. In The Biliary System. A Symposium of the NATO advanced Study Institute, edited by W. Taylor, pp. 515-529. Blackwell, Oxford.

Siegel, S. (1956). Nonparametric Statistics for the Behavioral Sciences. McGraw Hill, New York.
Sinclair, I. S. R. (1956). Observations on a case of external pancreatic fistula in man. Brit. J. Surg., 44, 250-262.

Thureborn, E. (1962). Human hepatic bile. Composition changes due to altered enterohepatic circulation. Acta chir. scand., suppl. 303.

Van Proosdij-Hartzema, E. G., Janssen, P., and De Jongh, D. K. (1955). Substituted phenylpropylamines. III. Anticholinergic activity of quaternary ammonium bases derived from $\mathbf{R} 55$ (2,2-diphenyl-4-diisopropylamino-butyramide). Arch. int. Pharmacodyn., 103, 120-128.

Villaret, M., and Justin-Besancon, L. (1936). Physiologie de la sécrétion pancréatique de l'homme étudiée par la fistulisation du canal de Wirsung. Nutrition (Paris), 6, 209-222.

White, T. T., Lundh, G., and Magee, D. F. (1960). Evidence for the existence of a gastropancreatic reflex. Amer. J. Physiol., 198, 725-728.

-, Alexander A. Mc., and Magee, D. F. (1963). The effect of gastric distension on duodenal aspirates in man. Gastroenterology, 44, 48-51.

Zaterka, S., and Grossman, M. I. (1966). The effect of gastrin and histamine on secretion of bile. Gastroenterology, 50, 500-505. 